DOI: https://doi.org/10.31933/jimt.v2i5 Received: 20 April 2021, Revised: 25 Mei 2021, Publish: 8 Juli 2021

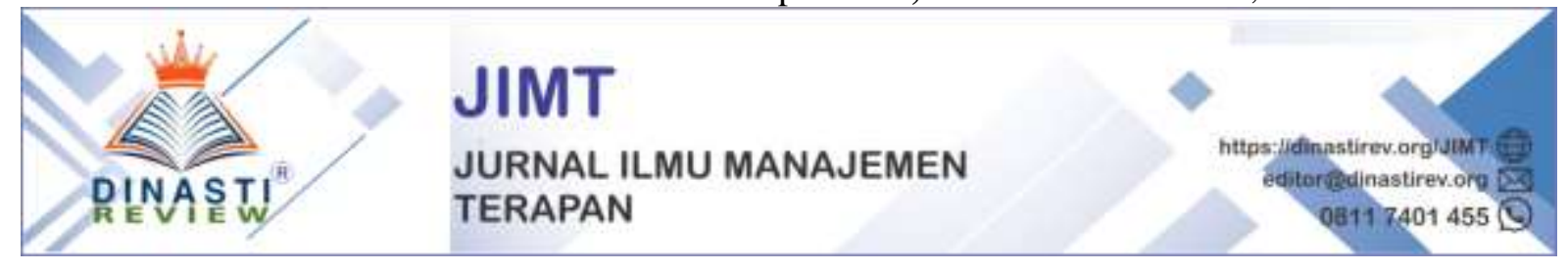

\title{
FAKTOR MANAJEMEN PROFESIONAL:PERENCANAAN, PENGORGANISASIAN, DAN PENGENDALIAN (SUATU KAJIAN STUDI LITERATUR MANAJEMEN SUMBERDAYA MANUSIA)
}

\author{
Rudi Ahmad, Aditya Pratama ${ }^{2}$ \\ ${ }^{1)}$ Mahasiswa Program Sarjana Teknik Industri, Universitas Mercu Buana Jakarta, \\ rudiahmad820@gmail.com \\ ${ }^{2}$ Mahasiswa Program Sarjana Teknik Industri, Universitas Mercu Buana Jakarta, \\ Adityapratama110995@gmail.com
}

\section{Corresponding Author: Rudi Ahmad ${ }^{1}$}

Abstrak: Riset terdahulu atau riset yang relevan sangat penting dalam suatu riset atau artikel ilmiah. Riset terdahulu atau riset yang relevan berfungsi untuk memperkuat teori dan penomena hubungan atau pengaruh antar variable. Artikel ini mereview Faktor-faktor yang mempengaruhi manajemen profesional, yaitu: perencanaan, pengorganisasian, dan kontrol, suatu studi literatur Manajemen Sumberdaya Manusia. Hasil artikel literature review ini adalah: 1) perencanaan berpengaruh terhadap manajemen Profesional; 2) pengorganisasian berpengaruh terhadap manajemen profesional; dan 3) kontrol berpengaruh terhadap manejemn profesional.

Kata Kunci: nilai, pengorganisasian, kontrol

\section{PENDAHULUAN}

\section{Latar Belakang Masalah.}

Setiap mahasiswa baik Strata 1, Strata 2 dan Strata 3, di wajibkan untuk melakukan riset dalam bentuk skripsi, tesis dan disertasi. Begitu juga bagi dosen, peneliti dan tenaga fungsional lainya aktif melakukan riset dan membuat artikel ilmiah untuk di publikasi pada jurnal-jurnal ilmiah.

Karya ilmiah merupakan sebagai salah syarat bagi mahasiswa untuk menyelasaikan studi pada sebagian besar Perguruan Tinggi di Indonesia. Ketentuan ini berlaku hampir untuk level jenjang pendidikan yaitu strata satu (S1) berupa Skripsi, untuk mahasiswa strata dua (S2) berupa Tesis, dan untuk mahasiswa strata tiga (S3) berupa Disertasi. 
Berdasarkan pengalaman empirik banyak mahasiswa dan author yang kesulitan dalam mencari artikel pendukung untuk karya ilmiahnya sebagai penelitian terdahulu atau sebagai penelitian yang relevan. Artikel yang relevan di perlukan untuk memperkuat teori yang di teliti, untuk melihat hubungan antar variable dan membangun hipotesis, juga sangat diperlukan pada pembahasan hasil penelitian.

Artikel ini menganalisis perencanaan $\left(\mathrm{X}_{1}\right)$ Pengorganisasian $\left(\mathrm{X}_{2}\right)$, dan Kontrol $\left(\mathrm{X}_{3}\right)$ terhadap Manajemen Profesional $\left(\mathrm{Y}_{1}\right)$, suatu studi literatur Manajemen Sumberdaya Manusia (MSDM).

\section{Rumusan Masalah.}

Berdasarkan latar belakang akan di rumuskan masalah yang akan di bahas pada artikel literature review agar lebih focus pada kajian pustaka dan hasil serta pembahasan nanti, yaitu:

1) Apakah perencanaan memiliki hubungan dan berpengaruh terhadap manajemen profesional.

2) Apakah pengorganisasian memiliki hubungan dan berpengaruh terhadap manajemen profesional.

3) Apakah kontrol memiliki hubungan dan berpengaruh terhadap manajemen profesional.

\section{KAJIAN PUSTAKA \\ Perencanaan (Planning)}

Menurut Burhanuddin (1994), Perencanaan pada hakekatnya adalah aktifitas pengambilan keputusan tentang sasaran (obyektivitas) apa yang akan dicapai, tindakan apa yang akan diambil dalam rangka mencapai tujuan atau sasaran dan siapa yang akan melaksanakan tugas-tugas tersebut. Dalam manajemen, fungsi perencanaan sangatlah jelas yaitu sebagai penentu langkah berikutnya. Perencanaan adalah kegiatan yang akan dilakukan di masa yang akan datang untuk mencapai tujuan. Perencanaan mengandur unsur-unsur (1) sejumlah kegiatan yang ditetapkan sebelumnya, (2) adanya proses, (3) hasil yang ingin dicapai, dan (4) menyangkut masa depan dalam waktu tertentu (Usman, 2008: 61).

Perencanaan merupakan upaya membuat kegiatan agar lebih fokus dan terarah. Hal tersebut sesuai dengan pendapat Sa'ud \& Makmun (2014: 3-4) pada hakikatnya perencanaan adalah suatu rangkaian proses kegiatan menyiapkan keputusan mengenai apa yang diharapkan terjadi (peristiwa, keadaan, suasana, dan sebagainya) dan apa yang akan dilakukan (intensifikasi, eksistensifikasi, revisi, renovasi, substitusi, kreasi, dan sebagainya). Rangkaian proses kegiatan itu dilaksanakan agar harapan tersebut dapat terwujud menjadi kenyataan di masa yang akan datang.

Selanjutnya, Kurniadin \& Machali (2016: 139) menyatakan bahwa perencanaan pada dasarnya adalah sebuah proses kegiatan yang menyiapkan secara sistematis kegiatan-kegiatan yang akan dilakukan untuk mencapai tujuan tertentu. Sebagai salah satu fungsi manajemen, perencanaan mempunyai peran sangat penting dan utama, bahkan yang pertama diantara fungsi-fungsi manajemen lainnya. Begitu pentingnya sebauh perencanaan sehingga dikatakan 
"Apabila perencanaan telah selesai dan dilakukan dengan benar, sesungguhnya sebagian pekerjaan besar telah selesai dilaksanakan."

Perencanaan berarti menentukan apa yang akan dilaksanakan sebagaimana yang dipaparkan oleh Siagian (2015: 88) Planning dapat didefinisikan sebagai "keseluruhan proses pemikiran dan penentuan secara matang tentang hal-hal yang akan dikerjakan di masa yang akan datang dalam rangka pencapaian tujuan yang telah ditentukan." Untuk sekedar mempertegas perbedaan fungsi tersebut pada tingkat administrasi dan manajemen, dapat dikatakan bahwa administrative planning mencakup segala aspek kegiatan dan meliputi seluruh unit organisasi, sedangkan managerial planning bersifat departemental dan operasional. Administrative planning merupakan hasil pemikiran dan penentuan yang bersifat garis besar, sedangkan managerial planning bersifat lebih khusus dan rinci.

Sependapat dengan itu, Uno (2011: 2) menjelaskan perencanaan yakni suatu cara yang memuaskan untuk membuat kegiatan dapat berjalan dengan baik, disertai dengan berbagai langkah yang antisipatif guna memperkecil kesenjangan yang terjadi sehingga kegiatan tersebut mencapai tujuan yang telah ditetapkan. Selanjutnya ditambahkan oleh Terry (2008: 46) perencanaan merupakan pemilihan dan menghubungkan fakta, menggunakan asumsiasumsi tentang masa depan dalam membuat visualisasi dan perumusan kegiatan yang diusulkan dan memang diperlukan untuk mencapai hasil yang diinginkan.

Kemudian Siagian (2005: 36-37) berpendapat bahwa perencanaan merupakan usaha sadar dan pengambilan keputusan yang telah diperhitungkan secara matang tentang hal-hal yang akan dikerjakan di masa depan dalam dan oleh suatu organisasi dalam rangka pencapaian tujuan yang telah ditentukan sebelumnya. Definisi sederhana di atas sesungguhnya mengandung empat pokok pikiran sebagai berikut:

Suatu rencana tidak akan timbul dengan sendirinya melainkan lahir sebagai hasil pemikiran yang bersumber pada hasil penelitian yang telah dilakukan. Artinya, kegiatan penelitian harus mendahului perencanaan, atau paling sedikit sebagai bagian integral dari keseluruhan kegiatan perencanaan.

Para manajer selaku perencana mutlak perlu memiliki keberanian mengambil keputusan dengan segala risikonya. Dikatakan demikian karena memang benar bahwa suatu rencana adalah keputusan yang hendak dilaksanakan di masa yang akan datang dan salah satu ciri masa depan ialah ketidakpastian.

Orientasi suatu rencana ialah masa depan. Perlu ditekankan bahwa perencanaan bukanlah usaha untuk meramalkan suatu masa depan secara umum, melainkan menentukan bentuk dan sifat masa depan yang diinginkan oleh organisasi. Sejarah perjalanan organisasi harus dijadikan sebagai bahan pemikiran dalam menentukan arah yang hendak ditempuh di masa yang akan datang.

Rencana harus mempunyai makna bahwa apabila rencana itu dilaksanakan, ia akan mempermudah usaha yang akan dilakukan dalam pencapaian tujuan organisasi yang bersangkutan. 
Dengan demikian, dari beberapa definisi diatas dapat disimpulkan bahwa perencanaan adalah proses dasar dari fungsi manajemen yang sangat penting dalam menentukan arah kegiatan selanjutnya, dengan adanya perencanaan maka suatu kegiatan atau aktivitas yang akan dilaksanakan menjadi lebih terarah dan dengan perencanaan yang baik maka tujuan dari suatu kegiatan dapat tercapai dengan baik pula.

disiplin kerja, dan lain sebagainya. Adapun faktor-faktor yang mempengaruhi Manajemen Profesional di gambarkan sebagai berikut:

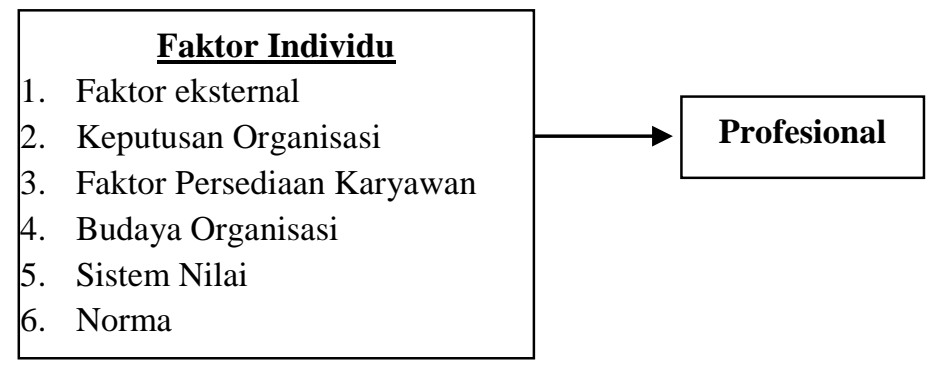

\section{Gambar 1: Faktor-faktor Yang Mempengaruhi Manajamen Profesional}

Menurut (Handoko, 1997, p. 55-57) fakto yang memepengaruhi manajemen profesional dapat di ukur melalui: 1) Faktor Eksternal, 2) Keputusan Organisasi, 3) Faktor Persediaan Karyawan.

Perencanaan (Planning) sudah banyak di teliti oleh peneliti sebelumnya diantaranya adalah: (Ali et al., 2016), (Prihartono \& Ali, 2020), (Harini et al., 2020), (Riyanto, Pratomo, et al., 2017), (Brata, Husani, Hapzi, 2017), (Agussalim, Kristin, et al., 2016), (Desfiandi et al., 2017), (Sulaeman et al., 2019), (Djojo \& Ali, 2012), (Riyanto, Sutrisno, et al., 2017), (Prayetno \& Ali, 2017), (Ridwan et al., 2020), (Djoko Setyo Widodo, P. Eddy Sanusi Silitonga, 2017), (Agussalim, Ayu Rezkiana Putri, et al., 2016), (Burhanuddin et al., 1994), (Usman. H, 2008), (Ssa'ud, S \& Makmun A. S, 2014), (Kurniadin, D. \& Maschali, I, 2016), (Siagian et al., 2005), (Uno, et al., 2011), (Anri Ferianto 2015),

\section{Manajemen Profesional}

Menurut David H. Maister sebagaimana dikutip oleh Andreas Harefa profesionalisme terutama masalah sikap, bukan seperangkat kompetensi. Seorang profesional sejati merupakan seorang teknisi yang peduli. Sedangkan makna profesional kadang ada kerancuan karena selalu dikaitkan dengan uang. Banyak orang mengatakan "Saya kerja professional gaji saya sekian." Mereka tidak memikirkan hal-hal lainnya, padahal makna profesional itu bekerja dengan maksimal dan penuh komitmen dan kesungguhan. Penjelasan dan makna profesionalisme tidak bisa lepas dari tiga aspek, yaitu pengetahuan (Knowledge), keahlian (Skill), dan sikap mental (Attitude). Ketiga aspek tersebut sama pentingnya dan setara sebagai fondasi dimana kuwalitas-kuwalitas profesionalisme itu dibangun, dikembangkan dan diasuh terus menerus. Kombinasi ketiga komponen itulah substansi konsep profesionalisme.

Beberapa aspek professional tersebut selanjutnya menjadi dasar terbentuknya manajemen profesional. Manajemen profesional menurut Louis Allen adalah sistem dalam 
organisasi yang memungkinkan berjalannya fungsi-fungsi manajemen, yaitu planning, organizing, leading, dan controlling.

Manajamen adalah gabungan pelaksanaan fungsi-fungsi perencanaan (Planning), pengorganisasian (Organizing), pelaksaan (Actutiting), dan pengawasan/pengendalian (controlling) untuk mencapai suatu tujuan tertentu dalam waktu yang di tentukan.

Manajemen Profesional didalam konteks SDM adalah pelaksanaan fungsi-fungsi tersebut dalam pengembangan mutu SDM secara profesional. Lawannya adalah manajemen amatiran yang ciri-ciri bertentangan dengan ciri-ciri manajemen profesional. Ciri-ciri manajemen profesional dalam pengenmbangan mutu SDM dapat dilihiat dari sisi operasional dan manajerial yakni :

1. Memperoleh dukungan top manajemen.

2. Bermanfaat untuk kepentingan internal dan juga eksternal organisasi.

3. Memiliki program jangka panjang dan berkesinambungan.

4. Berorientasi ke masa depan dengan pendekatan holistic (menyentuh unsur perasaan/spiritual)

5. Melaksakan prinsip efisiensi dan efektivitas.

6. Melakukan tindakan secara terencana/terprogram.

7. Melakukan monitoring, evaluasi serta menerima umpan-balik.

8. Karyawan dan pimpinan unit yang :

a. Memiliki kompetensi atau keahlian dan pengalaman panjang di bidangnya.

b. Haus dan berani pada tantangan.

c. Inovatif, kreatif, inisiatif dan efisien.

d. Memiliki integritas tinggi.

e. Menghargai profesi lain.

f. Selalu siap menghadapi segala risiko.

g. Bertanggung jawab atas setiap kata dan perbuatannya.

9. Mampu menggunakan teknologi tepat guna.

10. Kepemimpinan dalam membangun komitmen.

Manajemen Profesional sudah banyak di teliti oleh peneliti sebelumnya diantaranya adalah : (Mangkuprawira, Hubeis et, al,. 2007),

\section{Pengorganisasian (organizing)}

Kemampuan manager untuk memotivasi, mempengaruhi, mengarahkan, dan berkomunikasi dengan bawahannya akan menentukan efektifitas manager. Bagian pengarahan dan pengembangan organisasi dimulai dengan bab motivasi, karna para manajer tidak dapat mengarahkan kecuali bawahan untuk bersedia mengikutinya, motivasi merupakan kegiatan yang mengakibatkan, menyalurkan dan memelihara perilaku manusia, motivasi ini merupakan subjek yang paling penting bagi manager, kerna menurut definisi, manager harus berkerja dengan dn melalui orang lain 
Organisasi adalah kumpulan dari orang orang yang saling terintegrasi bekerjasama untuk tujuan yang sama, yaitu kesejahterahan organisasi dan anggotanya, agar pelaksanaan kerja dalam organisasi dapat berjalan sebagaimana mestinya maka dibutuhkan sumber seperti perlengkapan, metode kerja, bahan baku, dan lain lain, efektifitas dalam pencapaian target merupakan tujuan semua organisasi. Tentunya efektifitas dalam pencapaian hasil memerlukan adanya upaya dalam mengelola sumber yang dimiliki oleh organisasi, siagian (1992) mengatakan bahwa untuk mengatur dan mengarahkan sumber daya disebut dengan manajemen, sedangkan inti dari manajemen adalah kepemimpinan(leadership).

\section{Pengendalian (controlling)}

Pengawasan (controlling) merupakan salah satu fungsi paling penting manajemen arti suatu organisasi. Dimana, pengawasan (controlling) memiliki arti suatu proses mengawasi dan mengevaluasi suatu kegiatan. Suatu pengawasan dikatakan penting karna tanpa adanya pengawasan yang baik tentunya akan menghasilkan tujuan yang kurang memuaskan, baik bagi organisasi itu sendiri maupun bagi para pekerjanya. Didalam suatu organisasi terdapat tipe tipe pengawasan yang digunakan seperti :

1. Pengawasan pendahuluan ( preliminary control)

2. Pengawasan pada saat kerja berlangsung ( cocurrent control)

3. Pengawasan feed back ( feed back control)

Didalam proses pengawasan juga diperlukan tahap tahap pengawasan untuk mencapai tujuan yang diinginkan, tahap tahap pengawasan tersebut terdiri dari beberapa macam, yaitu :

1. Tahap penetapan standar

2. Tahap penentuan pengukuran pelaksanaan kegiatan

3. Tahap pengukuran pelaksanaan kegiatan

4. Tahap pembandingan pelaksanaan dengan standar dan Analisa penyimpangan

5. Tahap pengambilan Tindakan koreksi

Suatu organisasi juga memiliki perancangan proses pengawasan, yang berguna untuk merencanakan secara sistematis dan terstruktur agar proses pengawasan berjalan sesuai denga napa yang dibutuhkan atau direncanakan, untuk menjalankan proses pengawasan tersebut dibutuhkan alat bantu manajerial dikarenakan jika terjadi kesalahan dalam suatu proses dapat langsung diperbaiki, selain itu , pada alat alat bantu pengawasan ini dapat menunjang terwujudnya proses pengawasan yang sesuai dengan kebutuhan, pengawasan juga meliputi bidang bidang pengawasan yang menunjang keberhasilan dari suatu tujuan organisasi diantaranya.

Pengawasan bisa didefinisikan sebagai suatu usaha sistematis oleh manajemen bisnis untuk membandingkan kinerja standar, rencana, atau tujuan yang telah ditentukan terlebih dahulu untuk menentukan apakah kinerja sejalan dengan standar tersebut dan untuk mengambil Tindakan penyembuhan yang diperlukan untuk melihat bahwa sumber daya manusia digunakan dengan seefektif dan seefisien mungkin didalam mencapai tujuan. 


\section{METODE PENULISAN}

Metode penulisan artikel ilmiah ini adalah dengan metode kualitatif dan studi literature atau Library Research. Mengkaji Buku-buku literature sesuai dengan teori yang di bahas khusunya di lingkup Manajemen Sumberdaya Manusia (MSDM). Disamping itu menganalisis artikel-artikel ilmiah yang bereputasi dan juga artikel ilmiah dari jurnal yang belum bereputasi. Semua artikel ilmiah yang di citasi bersumber dari Mendeley dan Scholar Google.

Dalam penelitian kualitatif, kajian pustaka harus digunakan secara konsisten dengan asumsi-asumsi metodologis. Artinya harus digunakan secara induktif sehingga tidak mengarahkan pertanyaan-pertanyaan yang diajukan oleh peneliti. Salah satu alasan utama untuk melakukan penelitian kualitatif yaitu bahwa penelitian tersebut bersifat eksploratif, (Ali \& Limakrisna, 2013).

Selanjutnya dibahas secara mendalam pada bagian yang berjudul" Pustaka Terkait" (Related Literature) atau Kajian pustaka("Review of Literature"), sebagai dasar perumusan hipotesis dan selanjutnya akan menjadi dasar untuk melakukan perbandingan dengan hasil atau temuan-temuan yang terungkap dalam penelitian, (Ali \& Limakrisna, 2013).

\section{PEMBAHASAN}

Artikel ini menganalis dan membahas tentang variabel-variabel Manajemen Sumber Daya Manusia (MSDM) yaitu: Manajemen Profesional, Perencanaan (Planning), Pengorganisasioan (Organizing), dan Pengendalian (Controlling). Dimana Komitmen Perencanaan (Planning), Pengorganisasian, dan Pengendalian (Controlling), berpengaruh terhadap Manajemen Profesional, Riset dan artikel terdahulu dan relevan dengan artikel ini di antarnya adalah:

\section{1) Perencanaan berpengaruh terhadap manajemen profesional}

Perencanaan adalah proses mendefinisikan tujuan organisasi, membuat strategi untuk mencapai tujuan itu, dan mengembangkan rencana aktivitas kerja organisasi (Anri Ferianto 2015).

George R. Terry dalam bukunya Principles of Management (Sukarna, 2011: 10) mengemukakan tentang Planning sebagai berikut, yaitu .Perencanaan adalah pemilih fakta dan penghubungan fakta-fakta serta pembuatan dan penggunaan perkiraan-perkiraan atau asumsiasumsi untuk masa yang akan datang dengan jalan menggambarkan dan merumuskan kegiatankegiatan yang diperlukan untuk mencapai hasil yang diinginkan.

Menurut Stephen Robbins dan Marry Coulter menegemukaan tujuan dari perencanaan dari manajemen itu adalah :

1. Untuk memberikan pengarahan yang baik kepada manajer dan karyawan.

2. Untuk mengurangi tidak pastian.

3. Untuk meminimalisir pemborosan.

4. Untuk menetapkan tujuan dan standara yang akan digunakan dalam proses pengontrolan dan pengevaluasian.

5. Untuk mengetahui kapan dan selesainya suatu kegiatan tersebut.

6. Untuk mengurangi kegiatan-kegiatan yang tidak produktif dan untuk menghemat biaya, tenaga kerja, dan waktu.

Teori ini sejalan sejalan dengan penelitian yang dilakukan oleh (Ali et al., 2016), (Prihartono \& Ali, 2020), (Harini et al., 2020), (Riyanto, Pratomo, et al., 2017), (Brata, Husani, 
Hapzi, 2017), (Agussalim, Kristin, et al., 2016), (Desfiandi et al., 2017), (Sulaeman et al., 2019), (Djojo \& Ali, 2012), (Riyanto, Sutrisno, et al., 2017), (Prayetno \& Ali, 2017), (Ridwan et al., 2020), (Djoko Setyo Widodo, P. Eddy Sanusi Silitonga, 2017), (Agussalim, Ayu Rezkiana Putri, et al., 2016), (Burhanuddin et al., 1994), (Usman. H, 2008), (Ssa'ud, S \& Makmun A. S, 2014), (Kurniadin, D. \& Maschali, I, 2016), (Siagian et al., 2005), (Uno, et al., 2011), dan (Anri Ferianto 2015), yang mengemukakan bahwa perencanaan berpengaruh terhadap manajemen profesional.

mampu mengarahkan pegawainya untuk dapat bekerja secara maksimal dalam pencapaian tujuan organisasi.

\section{2) Pengorganisasian berpengaruh terhadap manajemen profesional}

Secara konseptual ada dua batasan yang perlu dikemukakan, yakni istilah "organization" sebagai kata benda dan "organizing" (pengorganisasian) sebagai kata kerja, menunjukkan pada rangkaian aktivitas yang harus dilakukan secara sistematis.

Istilah organisasi memiliki dua arti umum, pertama, mengacu pada suatu lembaga (institution) atau kelompok fungsional, sebagai contoh kita mengacu pada perusahaan, badan pemerintah, rumah sakit, atau suatu perkumpulan olahraga. Arti kedua mengacu pada proses pengorganisasian, sebagai salah satu dari fungsi manajemen.

Menurut Drs. M. Manullang Organisasi dalam arti dinamis disebut pengorganisasian, dan dalam arti statis disebut organisasi.

Menurut Stoner : Organisasi adalah suatu pola hubungan-hubungan yang melalui mana orang-orang di bawah pengarahan manajer mengejar tujuan bersama.

Menurut James D. Mooney : Organisasi adalah bentuk setiap perserikatan manusia untuk mencapai tujuan bersama.

Menurut Chester I. Bernard: Organisasi merupakan suatu sistem aktivitas kerja sama yang dilakukan oleh dua orang atau lebih.

Menurut Prof. Dr. Sondang P. Siagian: Organisasi adalah suatu bentuk persekutuan antara dua orang atau lebih yang bekerja bersama serta secara formal terikat dalam rangka pencapaian tujuan yang telah ditentukan dan dalam ikatan itu terdapat seorang atau sekelompok orang yang disebut bawahan.

Menurut Prof. Dr. Mr. S. Pradjudi Atmosudiro: Organisasi adalah struktur tata pembagian kerja dan struktur tata hubungan kerja antara sekelompok orang pemegang posisi yang bekerja sama secara tertentu untuk bersamasama mencapai suatu tujuan tertentu.

Menurut Duncan (Thoha, 2005), perilaku organisasi adalah suatu studi yang menyangkut aspek-aspek tingkah laku manusia dalam suatu organisasi atau suatu kelompok tertentu.

Menurut (Rhoades \& Eisenberger, 2002) persepsi terhadap dukungan organisasi mengacu pada persepsi karyawan mengenai sejauh mana organisasi menilai kontribusi mereka dan peduli pada kesejahteraan hidup mereka. Jika karyawan menganggap bahwa dukungan organisasi yang di terimanya tinggi, maka karyawan tersebut akan menyatukan keanggotaan sebagai anggota organisasi ke dalam identitas diri mereka dan kemudian mengembangkan hubungan dan persepsi yang lebih positif terhadap organisasi tersebut.

Artinya Semakin tinggi dukungan organisasi yang dirasakan oleh karyawan akan meningkatkan kinerja karyawan di dalam perusahaan. Adapun dukungan organisasi persepsian dapat dilihat dari penghargaan yang diterima karyawan, kesempatan pengembangan kemampuan, kondisi kerja serta kepedulian perusahaan terhadap kesejahteraan hidup 
karyawan. Hasil ini mendukung teori (Rhoades \& Eisenberger, 2002) yang menyatakan bahwa dukungan organisasi yang dimiliki seorang karyawan secara psikologis dapat mempengaruhi kinerja karyawan tersebut.

\section{3) Pengendalian berpengaruh manajemen profesional}

Menurut Jones and George (2003:331) mengenai pengertian pengendalian (controlling) ini, Pengendalian adalah proses dimana para manajer memantau dan mengatur bagaimana sebuah organisasi dan segenap anggotanya menjalankan kegiatan yang diperlukan untuk mencapai tujuan organisasi secara efisien dan efektif. Dalam pengendalian, para manajer memantau dan mengevaluasi apakah strategi dan struktur organisasi bekerja seperti yang dikehendaki, bagaimana hal-hal tersebut dapat ditingkatkan dan bagaimana harus diubah jika tidak bekerja.

Sistem kontrol manajemen yang dirancang dalam suatu organisasi harus memenuhi karakteristik sebagai berikut:

- Sistem pengendalian manajemen harus selaras erat dengan strategi dan tujuan organisasi.

- Sistem kontrol manajemen harus dirancang sesuai struktur organisasi dan tanggung jawab pengambilan keputusan manajer individual.

- Sistem pengendalian manajemen yang efektif harus memotivasi manajer dan karyawan untuk mengerahkan upaya ke arah pencapian tujuan organisasi melalui berbagai penghargaan terkait dengan pencapaian tujuan tersebut.

Menurut Hamel dan Prahalad (Rangkuti,2008,p3) "Strategi merupakan alat untukmencapai tujuan perusahaan dalam kaitannya dengan tujuan jangka panjang, programtindak lanjut, serta prioritas alokasi sumber daya".

Pengendalian manajemen profesional sudah banyak di teliti oleh peneliti sebelumnya diantaranya adalah: (jones, Geogre et al,. 2003), (Rangkuti et al,. 2008),

\section{Conceptual Framework}

Berdasarkan Kajian teori dan hubungan antar variabel maka model atau Conceptual Framework artikel ini dalam rangka menbagunan hipotesis adalah sebagai berikut:

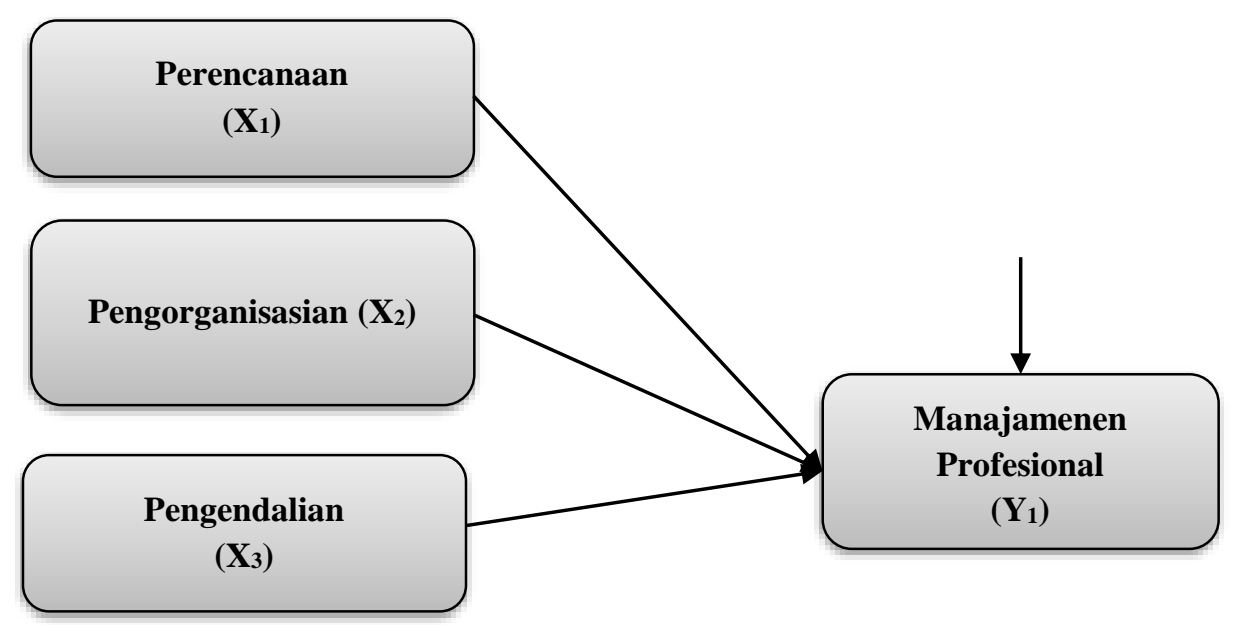




\section{Gambar 3: Conceptual Framework}

Perencanaan (x1), Pengorganisasian (x2) dan Pengendalian (x3) berpengaruh terhadap Manajemen Profesonal (y1).

Selain dari tiga variabel exogen ini yang mempengaruhi manajemen profesional (y1), masih banyak variabel lain yang mempengaruhinya diantaranya adalah:

1) Budaya Organisasi (x4): (Mangkuprawira et al., 2007),

2) Sistem Nilai (x5): (mangkuprawira et al., 2007),

3) Norma (x6): (Mangkuprawira et al., 2007),

\section{KESIMPULAN DAN SARAN}

\section{Kesimpulan}

Berdasarkan pembahasan, maka dapat disimpulkan untuk membangun suatu hipotesis guna untuk riset selanjutnya seperti di bawah ini:

1) Perencanaan ( $x 1$ ) berpengaruh terhadap Manajemen Profesional (y).

2) Pengorganisasian (x2) berpengaruh terhadap Manajemen Profesional (y).

3) Pengendalian (x3) berpengaruh terhadap Manajemen Profesional (y).

\section{Saran}

Bersdasarkan Kesimpulan di atas, maka saran pada artikel ini adalah bahwa masih banyak factor lain yang mempengaruhi Manajemen Profesional pada semua tipe dan level organisasi, oleh karena itu masih di perlukan kajian yang lebih lanjut untuk melengkapi factorfaktor lain apa sajakah yang dapat memepengaruhi Kinerja. Faktor lain tersebut seperti Budaya Organisasi (x4), Sistem Nilai (x5) dan Norma (x6)

\section{DAFTAR PUSTAKA}

Andreas Harefa, Membangkitkan Roh profesionalisme, (Jakarta:PT. Gramedia Pustaka Utama, 1999), Cet.2, hlm.112.

Didin Hafidhuddin dan Hendri Tanjung, Manajemen Syariah dalam Praktik, (Jakarta:

Gema Insani Press, 2003), Cet.1, hlm. 63.

Tanri Abeng, Dari Meja Tanri Abeng, Gagasan, Wawasan, Terapan dan Renungan, ( Jakarta: PT. Midas Surya Grafindo, 1997), Cet.1, hlm.3.

Burhanuddin, Analisis, Administrasi, Manajemen dan Kepemimpinan Pendidikan,

(Jakarta: Bumi Aksara, 1994), Cet.1, hlm. 167

Usman, H. (2008). Manajemen teori, praktik, dan riset pendidikan. Jakarta: PT. Bumi Aksara

Sa'ud, S. \& Makmun, A. S. Perencanaan pendidikan.

(Bandung: PT. Remaja Rosdakarya, 2014)

Kurniadin, D. \& Maschali, I. Manajemen pendidikan: konsep \& prinsip pengelolaan pendidikan. (Yogyakarta: Ar-Ruzz Media, 2016)

Siagian, S. P. Fungsi-fungsi manajerial. (Jakarta: PT. Bumi Aksara, 2005)

Siagian, S. P. Filsafat administrasi.(Jakarta: PT. Bumi Aksara, 2015)

Uno, H. B. Perencanaan Pembelajaran.(Jakarta: PT. Bumi Aksara, 2011)

Mangkuprawira, S dan Hubeis, A, Manajemen Mutu SDM, 
(Bogor: PT.Galia Indonesia, V,2007)

Mangkuprawira, S. 2007. Mengapa harus manajemen profesional,

http://ronawajah.wordpress.com/2007/05/14/mengapa-harus-manajemen-profesional/

Andri Feriyanto,S.E., dan Endang Shyta Trana,S.E., Pengantar Manajemen (3 in 1),

Yogyakarta, PT. Pustaka Baru, 2015, hal. 14.

Sukarna. Dasar-Dasar Manajemen. (Bandung: CV. Mandar Maju,2011)

Ali, H., Limakrisna, N., \& Jamaluddin, S. (2016). Model of costumer satisfaction: The empirical study at Bri in Jambi. Internasional Journal Of Applied Business and Management Studies. https://doi.org/10.21276/sjbms

Kadarman, A.M. et.al. 1996. Pengantar Ilmu Manajemen. Jakarta, Gramedia.

Handoko, T. Hani (2003), Manajemen. Edisi Kedua. Cetakan Kedelapanbelas. Yogyakarta: BPFE-Yogyakarta.

http://ariflobster.blogspot.com/2011/12/pengertian-organisasi-dan-manajemen.html

http://edwinnisme.wordpress.com/2011/11/28/pengorganisasian/

http://nadiyyazummi.blogspot.com/2012/10/makalah-pengantar-manajemen.html

http://darmansyah.weblog.esaunggul.ac.id/category/sistem-pengendalian-

manajemen/?gdezpoahydxsbcoj

Caronlin, Rona Tumiur Mauli. 2020. Modul Perkuliahan Sistem

PengendalianManajemen : Memahami Strategi, Jakarta : Elearning Mercu Buana 